\title{
Foreign Institutional Ownership and Corporate Cash Holdings: Evidence from Emerging Economies
}

\author{
Tiago Loncan \\ Department of Accounting $\& 3$ Finance \\ Strathclyde Business School \\ University of Strathclyde \\ 199 Cathedral Street \\ Glasgow, G4 OQU, United Kingdom \\ tiago.rodrigues-loncan@strath.ac.uk
}

\begin{abstract}
With the increased presence of foreign institutional investors in emerging stock markets, academic interest on the effects of foreign institutions on corporate managerial decisions has notably increased. This paper joins this debate by investigating the effects of foreign institutional ownership on cash holdings, a strategic corporate financing choice. Analysing a sample of firms from 23 emerging economies, the paper shows that, while foreign institutional ownership has a negative effect on cash holdings, it also increases the contribution of cash to firm valuation. These effects are potentially transmitted to cash through mitigation of agency conflicts and alleviation of financing constraints. In all, our findings suggest beneficial effects of foreign institutions on firms' financing structure, as foreign investors contribute to a more efficient and value-enhancing cash policy.
\end{abstract}

Keywords: Foreign institutional ownership, cash holdings, agency costs, financial liberalisation JEL codes: F65, F61, F36, G15, G12 


\title{
Foreign Institutional Ownership and Corporate Cash Holdings: Evidence from Emerging Economies
}

\begin{abstract}
With the increased presence of foreign institutional investors in emerging stock markets, academic interest on the effects of foreign institutions on corporate managerial decisions has notably increased. This paper joins this debate by investigating the effects of foreign institutional ownership on cash holdings, a strategic corporate financing choice. Analysing a sample of firms from 23 emerging economies, the paper shows that, while foreign institutional ownership has a negative effect on cash holdings, it also increases the contribution of cash to firm valuation. These effects are potentially transmitted to cash through mitigation of agency conflicts and alleviation of financing constraints. In all, our findings suggest beneficial effects of foreign institutions on firms' financing structure, as foreign investors contribute to a more efficient and value-enhancing cash policy.
\end{abstract}

Keywords: Foreign institutional ownership, cash holdings, agency costs, financial liberalisation JEL codes: F65, F61, F36, G15, G12

\section{Introduction}

Openness to cross-border finance has brought important changes to the architecture of emerging financial markets. Financial liberalisation has contributed a great deal to integrate developing countries' financial markets with the global financial system, mostly driven by foreign institutional investors' quest for diversification opportunities in emerging economies. On the other hand, whether foreign investors exert positive and desired effects on corporate behaviour remains an unsettled issue, and a matter of polemic debate at the corporate, policy and academic domains. As noted by Bena et al. (2017), foreign investors can be seen as locusts, for leading firms towards short-termed strategies because of an alleged lack of commitment with long-term value creation.

On the other hand, a growing literature has brought a different and rather positive perspective 
to what we know about how foreign institutional ownership affects corporate behaviour. We have learned from this literature that foreign institutions, instead of being locusts, actually bring about numerous beneficial effects for invested firms. Foreign institutions, against criticisms, are shown to foster long-term value creation by enhancing capital allocation via investments and innovations (Bena et al., 2017; Luong et al., 2017), improve corporate governance and monitoring (Huang \& Zhu, 2015; Aggarwal et al., 2011), lower the cost of equity capital (Hillier \& Loncan, 2017), and reduce stocks' liquidity commonality via more transparent corporate policies (Deng et al., 2018).

However, one thing we do not know, which is worth learning about given its importance for the theory and practice of finance, is whether and how foreign institutional ownership affects corporate financing choices, a strategic managerial decision. This study contributes new knowledge to this important debate on the effects of foreign institutional ownership on corporate behaviour, investigating if and how foreign investors affect corporate financing decisions via cash holdings policy. This issue is relevant because cash holdings choices have crucial ramifications into the optimal allocation of capital between financial and productive activities, and in safeguarding shareholders' wealth against expropriation of resources stored as cash reserves.

We exploit two theoretical channels linking foreign institutional ownership with cash holdings: mitigation of agency problems and alleviation of external finance constraints. First, while agency costs increase firms' propensity to accumulate liquid assets, as corporate insiders build up large cash balances envisaging expropriating cash at the expenses of investors (Nikolov \& Whited, 2014; Fresard \& Salva, 2010; Pinkowitz et al., 2006), foreign institutions can lower agency costs, by enhancing monitoring and corporate governance, reducing insiders' expropriation proclivity (Bena et al., 2017; Huang \& Zhu, 2015; Aggarwal et al., 2011; Ferreira \& Matos, 2008; Stulz, 2005).

Second, while firms accumulate more cash as a liquidity cushion, to insulate growth opportunities against costly external finance (Riddick \& Whited, 2009; Gamba \& Triantis, 2008), openness to cross-border finance via liberalisation and consequently the influx of foreign institutions to emerging markets lowers cost of capital and financing constraints, by enhancing risk sharing between domestic and foreign investors, and by increasing the supply of finance (Chari \& Henry, 2004; 
Laeven, 2003; Stulz, 1999). Building on these theoretical channels, we hypothesise that foreign institutional ownership reduces cash holdings. Also, foreign investors' enhanced monitoring may reduce expropriation risks priced in firms' stocks, increasing firm value and the value of cash. Thus, we further hypothesise that foreign institutions increase the contribution of cash to firm value.

These two hypotheses are empirically tested for a sample of 23 emerging economies. The empirical design consists of two analyses, in a similar spirit of Kalcheva \& Lins (2007)'s study of agency costs and cash holdings. First, cash holdings models are estimated to assess the effect of foreign institutional ownership on the amount of cash held by firms. Second, to analyse how and if the presence of foreign institutional investors affects the contribution of cash to firm valuation, Tobin's Q models are estimated, with cash holdings and foreign institutional ownership entering the model both linearly and interacted with one another.

Findings show that, as hypothesised, foreign institutional ownership is associated to marginal reductions in cash holdings, and that the presence of foreign institutional investors also augments the marginal contribution of cash to firm valuation. Statistical effects are also economically significant. A 1 standard deviation increase in foreign institutional ownership can reduce cash holdings by $0.75 \%$. With respect to valuation, while a 1 percentage point increase in cash holdings increases Tobin's Q by $0.54 \%$, out of which cash alone adds $0.489 \%$, foreign institutional ownership contributes with $0.052 \%$ via its interaction with cash. In other words, out of the total contribution of cash to firm value, foreign institutional ownership adds approximately $10 \%(0.05 / 0.54)$.

Crucially, we streamline our empirical testing with the theoretical channels linking foreign institutional ownership with cash holdings, e.g, agency costs and external finance costs, by investigating whether investor protection, monitoring by market analysts and the sensitivity of cash holdings to cashflows influence the effect of foreign institutional ownership on cash holdings. In general, we find convincing evidence that agency conflicts and external finance cost are two important channels connecting foreign institutional ownership to cash holdings. Furthermore, our results remained robust to a number of robustness checks, in particular regarding endogeneity problems.

The paper contributes to three main strands of research. First and foremost, this article 
accords novel evidence to the literature on the effects of foreign institutional ownership on corporate behaviour, as previously pointed out. Second, the study also provides new evidence to the firm-level financial liberalisation literature. While the extant literature analysed the effect of liberalisation on investment (Chari \& Henry, 2008), cost of capital (Chari \& Henry, 2004; Bekaert \& Harvey, 2000) and productivity (Larrain \& Stumpner, 2017), this paper brings a corporate finance approach by showing that, as a response to market liberalisation, firms adjust cash policy.

Third, we contribute to the literature examining the factors affecting cash holdings policies and the value of cash (Wu et al., 2017; Nikolov \& Whited, 2014; Fresard \& Salva, 2010; Dittmar \& Mahrt-Smith, 2007; Kalcheva \& Lins, 2007; Pinkowitz et al., 2006; Opler et al., 1999), by showing that foreign institutional ownership is a relevant determinant of cash holdings decisions, and that it also enhances the value-added of cash holdings. Moreover, whilst Ward et al. (2018) report positive effects of institutional investors' monitoring on the value of cash in the U.S, results from our paper validate such value-enhancing role played by institutional investors, extending such important result to the context of emerging economies as well.

Taken the results of the paper altogether, while foreign institutional ownership reduces cash balances, an important contribution of cash to firm valuation is arguably driven by foreign investors' disciplining insiders to make good use of cash. While cash reductions may liberate resources to more productive activities, mitigation of agency costs also explains the premium on the value of cash, because with foreign institutional investors watching insiders closely, the likelihood of expropriation becomes lower. In other words, foreign institutional investors may be contributing to a more economically efficient, but above all, more trustworthy cash policy to the eyes of shareholders.

The rest of the paper is organised as follows. Section Two brings the literature review and hypotheses development. Section Three presents the data, and Section Four the methods. Section Five brings the results, and Section Six tests the theoretical channels. Section Seven shows robustness tests, and Section Eight concludes. 


\section{Theoretical channels linking foreign institutional ownership and cash holdings}

Managerial agency problems and precautionary savings driven by costly external finance are both associated to higher cash accumulation (Amess et al., 2015). Foreign institutional ownership can mitigate agency problems and lower external finance cost, hence affecting cash policy through these channels. This section exploits these theoretical linkages and develops testable hypotheses.

Entrenched managers and insiders tend to build excessively high cash balances, envisaging expropriation of minority investors, thereby increasing their personal utility by diverting cash, tunnelling firms' resources to investments yielding private benefits or to perquisites consumption (Nikolov \& Whited, 2014; Kalcheva \& Lins, 2007; Pinkowitz et al., 2006).

As a consequence, the cost of external finance increases the higher is asymmetric information between insiders and external investors (Ozkan \& Ozkan, 2004). This is consistent with the prediction that excess cash holdings increases with the extent of asymmetric information (Harris \& Raviv, 2017). In light of this discussion, agency problems are associated to higher cash accumulation.

On the othe hand, foreign institutional ownership can mitigate such agency conflicts. The influx of foreign investors enhances shareholders' discipline on insiders, as firms rent more sophisticated monitoring technologies from developed countries (Stulz, 2005). While domestic investors may remain loyal to their ties with insiders and managers, foreign investors are more independent, taking a more active stance in monitoring invested firms (Ferreira \& Matos, 2008).

As a consequence of financial integration, corporate governance improves over time as a result of foreign stock ownership (Aggarwal et al., 2011), decreasing expropriation risks (Huang \& Zhu, 2015). By enhancing monitoring, foreign institutional ownership makes it more costly for insiders to expropriate, reducing insiders' incentive to hold cash for opportunistic reasons.

The cost of external finance also increases cash holdings. When firms fund investments with equity injections from shareholders, informational asymmetries and agency costs may result in an underpriced stock offer (Corwin, 2003; Altinkilic \& Hansen, 2003), and underwritting fees reduce the capital raised (Altinkilic \& Hansen, 2000), increasing the cost of external finance. To avoid these costs, firms often rely upon accumulated cash to fund investments (Opler et al., 1999). In 
particular, firms with more uncertain income, lumpy investment policy and financially constrained firms all tend to hold larger cash balances as a liquidity cushion to insulate investments (Riddick \& Whited, 2009; Almeida et al., 2004; Acharya et al., 2007; D’Mello et al., 2008). For this reason, cash derives its fundamental value by offering financial flexibility (Gamba \& Triantis, 2008).

Foreign institutional ownership can lower the cost of external finance. First, foreign investors enhance risk sharing with domestic investors, decreasing cost of capital (Chari \& Henry, 2004; Bekaert \& Harvey, 2000; Henry, 2000a). Second, the influx of foreign investors increases the supply of finance available to local firms (Stulz, 1999), contributing to reduce equity funding costs and alleviating financing constraints (Laeven, 2003).

Third, as foreign institutions bring enhanced governance and mitigate agency costs, investors demand a lower equity premium on firms' stocks, further reducing the cost of equity capital. By reducing cost of capital, foreign institutional ownership downplays the role of cash holdings in firms' financing structure. Because foreign institutional ownership can mitigate agency costs, and also lower the cost of external finance, we should expect a negative effect of foreign institutional ownership on cash holdings. This discussion leads to our first hypothesis:

Hypothesis H1: Foreign institutional ownership decreases corporate cash holdings.

On top of affecting how much cash firms hold, foreign institutional ownership can also affect the marginal value of cash holdings. Empirical evidence suggests that the marginal value of cash is lower in countries with lower institutional quality and weaker investor protection (Kalcheva \& Lins, 2007; Pinkowitz et al., 2006), and lower for firms with weaker corporate governance (Dittmar \& Mahrt-Smith, 2007). Evidence also suggests that institutional investors increase the marginal value of cash through enhanced monitoring (Ward et al., 2018).

In line with these findings, cross-listing via ADR (American Depositary Receipts) exposes emerging markets' firms to U.S investors' monitoring and governance standards, increasing firm value and the marginal value of cash too (Fresard \& Salva, 2010; Huang et al., 2013; Doidge et al., 
2004). This discussion suggests that foreign investors, through enhanced monitoring efforts, put managers at check to keep cash balances at levels consistent with shareholder wealth maximisation, reducing expropriation risks.

With investors trusting cash will be employed in the best interest of the firm, and not siphoned away to insiders' pockets, such lower expropriation risks are priced in firms' stocks, with stock prices and the marginal value of cash increasing as a response. This argument motivates our second hypothesis:

Hypothesis H2: Foreign institutional ownership increases the contribution of cash to firm value.

\section{Data and Variables}

The dataset includes non-financial firms located in 23 emerging economies. ${ }^{1}$ Firm-level data is obtained from the Osiris Database (Bureau Van Dijk), covering a period between 2006 and 2015, on a yearly basis. The dependent variable is cash holdings, calculated as cash and cash equivalents scaled by total assets. Foreign institutional ownership, the main explanatory variable, is the relative share of stocks which is held by foreign institutional investors. ${ }^{2}$ Firms with negligible foreign institutional ownership (below 1\%) are excluded from the core sample, but are analysed in robustness checks (Section 7.3), when foreign invested firms are distinguished from strictly domestically invested firms by means of a dummy variable.

A number of control variables which can affect cash policies are also included in the dataset, in line with the literature on the determinants of cash holdings (Chen et al., 2014; Kalcheva \& Lins, 2007; Ferreira \& Vilela, 2004; Dittmar et al., 2003; Opler et al., 1999). Control variables include Tobin's Q (market value of equity plus total debt, scaled by total assets), investments (net capital expenditures scaled by total assets), cashflows (operating cashflows scaled by total assets),

\footnotetext{
${ }^{1}$ The sample of countries is based on the constituent countries of MSCI Emerging Markets Index.

${ }^{2}$ Foreign institutional ownership is computed by summing across the equity holdings of mutual and pension funds, investment banks, financial institutions, insurance funds, private equity funds, sovereign wealth funds, foundations and hedge funds. The calculation of foreign institutional ownership does not include foreign direct investments by non-portfolio investors (i.e, investments with long-lasting economic interests).
} 
net working capital (current assets, net of cash, minus current liabilities, scaled by total assets), leverage (total debt scaled by assets), and dividend policy (a dummy variable taking the value of 1 if the firm pays dividends, and taking zero otherwise).

Additional variables are employed in robustness and extension tests. Analyst coverage works as a proxy for monitoring (calculated as the number of brokers providing price recommendations for firms' stocks), return on equity reflects profitability (calculated as net income scaled by total equity), and MSCI constituency works as an instrumental variable for foreign institutional ownership (a dummy taking the value of 1 if firms are constituents of MSCI Emerging Markets Index in a given year, and zero otherwise).

Firm-level data is complemented with country-level variables from various sources. The capital inflow liberalisation index calculated by Jahan \& Wang (2016) and the IMF (International Monetary Fund) works as a proxy for capital market openness. The index runs between $[0,1]$, with higher scores associated to more liberalised markets and lower barriers to the free influx of foreign financial investments.

The minority investor protection index, from World Bank Doing Business Report, works as a country-level proxy for agency costs (expropriation risks), with higher scores obtained by countries in the Index reflecting more stringent investor protection and hence lower agency costs. The anticorruption index from ICRG (International Country Risk Guide) is used as an alternative proxy for agency costs in robustness checks (section 7.3). A variables summary is shown in Table 1.

Descriptive statistics are shown in Table 2. The average cash ratio is $12 \%$, whereas the mean for foreign institutional ownership is $10 \%$. Average Tobin's Q ratio is 1.60, investment is $6 \%$ of total assets, cashflows correspond to $8.6 \%$ of total assets, whilst net working capital is $7 \%$ of total assets. Average leverage ratio is $50 \%$, and $78 \%$ of firms in the sample pay dividends. The average firm in the sample has total assets with value of USD 1,840 million, and is covered by 4.8 analysts.

Table 3 shows country-level averages for selected variables. While firms tend to hold more cash in countries like China, Taiwan, Philippines and Indonesia (above 10\%), cash holdings are more modest in places like Brazil, Chile, Colombia, Mexico and India (below 10\%). Foreign institutional 
Table 1: Variables Summary

\begin{tabular}{|c|c|c|c|c|}
\hline Variables & Legend & Calculation & Interpretation & Source \\
\hline Cash holdings & $\operatorname{cash}_{i t}$ & Cash/Assets & Cash Holdings & BVD \\
\hline Foreign institutional own. & fio $_{i t}$ & Share of Foreign Investors (\%) & Foreign Ownership & BVD \\
\hline Tobin's Q & $q_{i t}$ & $($ Market Cap + Debt) $/$ Assets & Growth/Valuation & BVD \\
\hline Investments & $i_{i t}$ & Capex/Assets & Investment Policy & BVD \\
\hline Cashflows & $c f_{i t}$ & Cashflows/Assets & Cashflows & BVD \\
\hline Working capital & $w c_{i t}$ & Current (Assets-Liabilities)/Assets & Liquid Assets & BVD \\
\hline Leverage & $l_{i t}$ & Total Debt/Assets & Capital Structure & BVD \\
\hline Return on equity & $r_{i t}$ & Net Income/Equity & Profitability & BVD \\
\hline MSCI constituency & $m s c i_{i t}$ & 1 if MSCI Constituent, 0 otw & Foreign Ownership IV & MSCI \\
\hline FIO (dummy) & $f i o_{i t}^{D}$ & 1 if foreign invested, 0 otw & Foreign Ownership & BVD \\
\hline Dividends (dummy) & $d_{i t}$ & 1 if $\mathrm{D}>0,0$ otw & Dividend Policy & BVD \\
\hline Total assets & $t a_{i t}$ & Total Assets in USD & Firm Size & BVD \\
\hline Analyst coverage & $\operatorname{acov}_{i}$ & Number of analysts & Monitoring & BVD \\
\hline Liberalisation & $l i b_{c t}$ & Index & Capital market openness & IMF \\
\hline Min. Investor protection & $\operatorname{mip}_{c}$ & Index & Agency costs & WB \\
\hline Anti-corruption & anticorrup $_{c t}$ & Index & Agency costs & ICRG \\
\hline
\end{tabular}

investors are more present in countries like Brazil, South Africa, Mexico and Poland (figures above $10 \%$ ). Tobin's Q is relatively higher in countries like Brazil, Indonesia, Russia, Philippines, South Africa and Czech Republic (near 2.0). Firms' investment is higher in China, Russia and India.

South Korea, Qatar, Arab Emirates, Chile, Peru, Czech Republic and Greece have higher liberalisation (scores closer to 1), whilst investor protection is stronger in South Korea, Colombia, Arab Emirates, Qatar, India and Malaysia (investor protection above 7 points). 
Table 2: Descriptive Statistics

This table presents descriptive statistics. Firm-year data from 23 emerging markets is collected from Osiris (BVD), covering a sample period of ten years (2006-2015). Cash holdings is calculated as cash and cash equivalents scaled by total assets; foreign institutional ownership is the share of foreign institutional investors relative to firms' total equity capital (alternatively measured as dummy, equal to 1 for the firms with foreign institutional ownership greater than zero, and equal to zero otherwise); Tobin's Q is calculated as the sum of market value of equity and total debt, scaled by total assets; investments is net capital expenditures scaled by total assets, cashflows is measured by operating cashflows scaled by total assets, leverage is total debt scaled by total assets, working capital is calculated as current assets, net of cash and cash equivalents, minus current liabilities, scaled by total assets; profitability is captured by return on equity, calculated as net income divided by total equity; MSCI is a dummy, taking the value of 1 if firms are constituents of MSCI Emerging Markets index in a given year, and zero otherwise; dividends payment is proxied by dummy, taking the value of 1 if firms pay dividends, and zero otherwise; analyst coverage is the total number of brokers providing recommendations on firms' stocks; liberalisation is a country-level measure of capital inflow liberalisation, by Jahan \& Wang (2016) and the IMF (International Monetary Fund), calculated as an index ranging between [0,1], with higher scores associated with more liberalised markets; expropriation risk is proxied by the minority investor protection index from the World Bank (WB), with higher scores associated to lower agency costs.

\begin{tabular}{|c|c|c|c|c|c|c|}
\hline Variables & Legend & Mean & Std. Dev. & 25\% Perc. & Median & 75\% Perc. \\
\hline Cash/Assets & cash $_{i t}$ & 0.120 & 0.122 & 0.034 & 0.081 & 0.169 \\
\hline Tobin's Q & $q_{i t}$ & 1.600 & 1.330 & 0.910 & 1.170 & 1.760 \\
\hline Investments/Assets & $i_{i t}$ & 0.061 & 0.063 & 0.016 & 0.041 & 0.083 \\
\hline Cashflows/Assets & $c f_{i t}$ & 0.082 & 0.088 & 0.040 & 0.076 & 0.127 \\
\hline Debt/Assets & 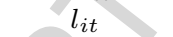 & 0.504 & 0.231 & 0.341 & 0.499 & 0.648 \\
\hline Net income/Equity & $r_{i t}$ & 0.137 & 0.189 & 0.057 & 0.138 & 0.229 \\
\hline MSCI (dummy) & $m s c i_{i t}$ & 0.140 & 0.360 & 0.000 & 0.000 & 0.000 \\
\hline Dividends (dummy) & $d_{i t}$ & 0.780 & 0.410 & 1.000 & 1.000 & 1.000 \\
\hline FIO (dummy) & $f i o_{i t}^{D}$ & 0.240 & 0.420 & 0.00 & 0.00 & 0.000 \\
\hline Total Assets (USD mm) & $t a_{i t}$ & $1,840.000$ & $3,180.000$ & 199.140 & 513.260 & $1,617.000$ \\
\hline Anti-corruption Index & anticorrup $_{c t}$ & 2.467 & 0.468 & 2.000 & 2.500 & 2.500 \\
\hline Observations & 24,939 & & & & & \\
\hline Firms & 5,015 & & & & & \\
\hline
\end{tabular}


Table 3: Descriptive Statistics (country averages)

Note: This Table presents country-level descriptive statistics. Firm-year data from 23 emerging markets is collected from Osiris (BVD), covering a sample period of ten years (2006-2015). The table below shows country averages for selected variables. Cash holdings is calculated as cash and cash equivalents scaled by total assets; foreign institutional ownership is the share of foreign institutional investors relative to firms' total equity capital; Tobin's Q is calculated as the sum of market value of equity and total debt, scaled by total assets; investments is net capital expenditures scaled by total assets, analyst coverage is the total number of brokers providing recommendations on firms' stocks; liberalisation is a country-level measure of capital inflows liberalisation, calculated as an index ranging between $[0,1]$, with higher scores associated with more liberalised markets; expropriation risk is proxied by the minority investor protection index from the World Bank (WB), with higher scores associated to lower agency costs; the last column shows the \% of firms each country contributes to the total sample.

\begin{tabular}{|c|c|c|c|c|c|c|c|c|}
\hline Countries & $\begin{array}{l}\text { Cash } \\
\text { cash }_{i t}\end{array}$ & $\begin{array}{l}\text { Foreign Own. } \\
\quad \text { fio }_{i t}\end{array}$ & $\begin{array}{c}\text { Tobin's Q } \\
q_{i t}\end{array}$ & $\begin{array}{c}\text { Investment } \\
i_{i t}\end{array}$ & $\begin{array}{l}\text { Analyst coverage } \\
\qquad a \operatorname{cov}_{i}\end{array}$ & $\begin{array}{l}\text { Liberalisation } \\
\qquad l i b_{c t}\end{array}$ & $\begin{array}{l}\text { Agency costs } \\
\text { mip }_{c}\end{array}$ & $\begin{array}{c}\text { Firms. } \\
\%\end{array}$ \\
\hline Arab Emirates & 0.14 & 0.06 & 1.02 & 0.03 & 4.17 & 0.79 & 6.00 & 0.39 \\
\hline Brazil & 0.07 & 0.18 & 1.75 & 0.05 & 5.67 & 0.43 & 6.50 & 4.16 \\
\hline Chile & 0.06 & 0.08 & 1.55 & 0.05 & 3.21 & 0.87 & 6.30 & 1.57 \\
\hline China & 0.20 & 0.09 & 1.58 & 0.07 & 5.48 & 0.03 & 4.30 & 6.58 \\
\hline Colombia & 0.06 & 0.09 & 1.64 & 0.06 & 1.36 & 0.14 & 7.30 & 0.42 \\
\hline Czech Rep. & 0.11 & 0.12 & 2.21 & 0.09 & 6.17 & 0.88 & 5.80 & 0.16 \\
\hline Egypt & 0.11 & 0.08 & 1.41 & 0.04 & 2.79 & 0.80 & 4.50 & 1.07 \\
\hline Greece & 0.12 & 0.12 & 1.28 & 0.04 & 3.09 & 0.86 & 6.20 & 1.43 \\
\hline Hungary & 0.11 & 0.14 & 1.50 & 0.10 & 3.70 & 0.28 & 5.50 & 0.27 \\
\hline Indonesia & 0.12 & 0.09 & 1.96 & 0.06 & 4.50 & 0.33 & 5.30 & 3.67 \\
\hline India & 0.08 & 0.09 & 1.87 & 0.08 & 8.10 & 0.11 & 7.30 & 17.34 \\
\hline South Korea & 0.09 & 0.08 & 1.47 & 0.07 & 5.21 & 0.87 & 7.30 & 14.18 \\
\hline Mexico & 0.08 & 0.15 & 1.70 & 0.06 & 5.61 & 0.26 & 5.80 & 1.70 \\
\hline Malaysia & 0.14 & 0.08 & 1.51 & 0.05 & 4.08 & 0.40 & 7.80 & 6.82 \\
\hline Peru & 0.09 & 0.14 & 1.55 & 0.07 & 2.45 & 0.98 & 6.00 & 0.51 \\
\hline Philippines & 0.13 & 0.11 & 1.74 & 0.05 & 4.89 & 0.27 & 3.80 & 1.65 \\
\hline Poland & 0.09 & 0.17 & 1.35 & 0.05 & 1.12 & 0.45 & 6.00 & 7.44 \\
\hline Qatar & 0.20 & 0.11 & 1.72 & 0.07 & 3.71 & 0.86 & 4.50 & 0.17 \\
\hline Russia & 0.09 & 0.11 & 1.96 & 0.11 & 4.25 & 0.45 & 5.70 & 1.85 \\
\hline Thailand & 0.08 & 0.09 & 1.56 & 0.06 & 7.09 & 0.40 & 6.30 & 4.49 \\
\hline Turkey & 0.12 & 0.09 & 1.29 & 0.06 & 4.31 & 0.51 & 6.80 & 3.36 \\
\hline Taiwan & 0.18 & 0.07 & 1.49 & 0.04 & 2.80 & . & 6.70 & 16.86 \\
\hline South Africa & 0.11 & 0.12 & 1.77 & 0.06 & 3.60 & 0.53 & 7.20 & 3.92 \\
\hline
\end{tabular}




\section{Empirical models}

\subsection{Cash holdings model}

We adopt an empirical strategy similar as employed by Ozkan \& Ozkan (2004) and estimate a dynamic panel data model via GMM (Generalised Method of Moments). Two reasons motivate this choice. First, as the theoretical cash literature suggests that holding cash is costly (Riddick \& Whited, 2009), this dynamic structure is appropriate for recognising delays and the partial nature of the adjustments in cash holdings due to the existence of adjustment costs. Such partial adjustment can be accounted for by including lagged cash in the model, which captures the speed of convergence of cash to its target level. Second, GMM estimation is required because cash holdings and foreign institutional ownership may be endogeneous, as foreign investors may have preferences for high-cash firms when selecting their investments (Dahlquist \& Robertsson, 2001).

Static OLS (Ordinary Least Squares) regression is another empirical strategy commonly employed in the literature, such as in Caprio et al. (2013), Kalcheva \& Lins (2007) and Dittmar et al. (2003). There are two important underlying assumptions behind OLS, though. One is that cash holdings follow a static structure, as lagged cash is usually not included in the models. Another is that the explanatory variables are exogenous to cash holdings. Hence, our core estimation strategy is more robust than the typical OLS model, being consistent with more stringent assumptions. In any case, we also estimate OLS regressions as robustness checks.

We now describe our empirical model. Cash holdings is modelled as a function of lagged cash, foreign institutional ownership and control variables. The cash model is shown in Equation 1:

$$
\operatorname{cash}_{i t}=\alpha_{i}+\alpha_{t}+\delta \cdot \operatorname{cash}_{i t-1}+\beta \cdot \text { fio }_{i t}+\gamma_{n} \cdot \text { controls }_{i t}+\epsilon_{i t}
$$

The vector of control variables includes Tobin's Q, investments, cashflows, working capital, leverage and dividends, plus year fixed effects. ${ }^{3}$ Inherent to dynamic panel data models, Equation

\footnotetext{
${ }^{3}$ Because cash holdings and the control variables are scaled by total assets, it is not necessary to include firm
} 
1 is first-differenced, with time-invariant unobserved heterogeneity, such as firm fixed effects, wiped out from the estimation. By using first-difference operators, endogeneity between regressors and firm-specific unobserved effects is dealt with, and the coefficient of foreign institutional ownership reads as a cleaner partial effect of the change in foreign institutional ownership's share on the change in cash holdings. 4 The first-differenced equation estimated is shown in Equation 2:

$$
\Delta \operatorname{cash}_{i t}=\delta \cdot \Delta \operatorname{cash}_{i t-1}+\beta \cdot \Delta \text { fio }_{i t}+\gamma_{n} \cdot \Delta \text { controls }_{i t}+\Delta \epsilon_{i t}
$$

Because $\Delta$ cash $_{i t-1}$ and $\Delta \epsilon_{i t}$ are correlated by construction, this positive covariance creates endogeneity biases, and estimation of the first-difference equation requires GMM (Greene, 2012; Arellano \& Bond, 1991; Anderson \& Hsiao, 1981). Moreover, as foreign investors may have preferences for high-cash firms, contemporaneous endogeneity might still affect the consistency of estimates. In light of this, in addition to treating the lagged dependent variable as an endogenous covariate, as standard practice in dynamic models, this treatment is also applied to foreign institutional ownership in the GMM procedure. Therefore, both lagged cash and foreign institutional ownership are instrumented via GMM-style instruments, building on the orthogonality condition between first-differenced errors, lagged cash levels and lagged foreign institutional ownership levels, while the remaining exogenous explanatory variables are instrumented by standard first-differences.

Model specification is assessed by employing two tests. First, the validity of instrumental variables is tested through the Sargan's test of over-identifying restrictions, with null hypothesis of instrument validity. Second, the Arellano-Bond test of second order serial correlation in firstdifferenced errors is also employed, with null hypothesis of absence of second-order correlation. This test is important because the orthogonality condition between first-differenced errors and lagged endogenous variables builds upon the assumption of absence of second-order correlation.

size as a control. The role of firm size receives special attention in Section 6.3. Return on assets, a variable often employed as a control, is redundant for its high correlation with cashflows, therefore not included in the model.

${ }^{4}$ First-differencing also wipes out the effects of other sources of time-invariant unobserved heterogeneity, such as country and industry effects. 


\subsection{Firm valuation model}

A second model is estimated, to study the impact of foreign institutional ownership on the contribution of cash to firm valuation. As common practice in the literature on corporate valuation, investor protection and cash holdings, firm valuation is proxied by Tobin's Q (Kalcheva \& Lins, 2007; Lins, 2003; Porta et al., 2002; Lang \& Stulz, 1994). In this literature, valuation is usually modelled as a function of cash holdings, plus other firm-level or country-level variables, generically labeled $x_{i t}$ (like governance), entering the model both with a stand-alone coefficient and, most importantly, interacted with cash holdings. This interactive term captures the effect of $x_{i t}$ on the marginal contribution of cash to firm valuation. In our setup, $x_{i t}$ is foreign institutional ownership. Tobin's Q is a function of cash holdings, foreign institutional ownership, and the interactive term between foreign ownership and cash, plus control variables, as specified in Equation 3 :

$$
(\log ) q_{i t}=\alpha_{i}+\alpha_{t}+\delta \cdot \operatorname{cash}_{i t}+\beta \cdot f i o_{i t}+\eta \cdot \operatorname{cash}_{i t} \cdot \text { fio }_{i t}+\gamma_{n} \cdot \text { controls }_{i t}+\epsilon_{i t}
$$

The $\eta$ coefficient captures the effect of foreign institutional ownership on the contribution of cash to firm valuation. The vector of control variables includes other factors affecting firm valuation, such as profitability (return on equity), investments (capital expenditures), capital structure (leverage), payout policy (dividends) and firm size (total assets). The model is estimated via panel regressions, with firm and year fixed effects and heteroskedasticity-robust standard errors.

\section{Results}

\subsection{The effect of foreign institutional ownership on cash holdings}

Estimation results of dynamic cash models are reported in Table 4. In the first column, a model with foreign ownership and a single control for lagged cash is shown. The effect of foreign institutional ownership on corporate cash holdings is statistically significant and negative $\left(-0.054^{* *}\right)$. Also, lagged cash loads positively and significantly on current cash $\left(0.44^{* * *}\right)$, validating the dynamic specification of the model. 
In the second column, estimation results for the fully-fledged model, with all control variables, is shown. Despite adding a number of controlling variables, the partial effect of foreign ownership on cash holdings remains statistically significant and negative, and the coefficient preserves its same order of magnitude $\left(-0.048^{* *}\right) .{ }^{5}$ The presence of the lagged dependent variable in the model means that the coefficients of independent variables read as short-term effects (Baltagi et al., 2009). The long-run effect of foreign institutional ownership can be obtained by computing $\beta /(1-\delta)$, where beta is the coefficient of foreign institutional ownership, and delta is the coefficient of lagged cash: $-0.048 /(1-0.367)=-0.075$. The economic effect of foreign institutional ownership on cash holdings seems important too. Quantitatively, a 1 standard deviation in foreign institutional ownership (0.112) is associated with a negative change of $0.75 \%$ in cash holdings.

Interpreting and discussing this negative coefficient in light of the theory and the extant literature, results provide evidence that foreign institutional ownership is associated with marginal reductions in firms' outstanding cash balances, suggesting that foreign investors may discipline insiders to divest on liquid assets to mitigate expropriation risks. This finding is consistent with the argument posited in extant research that foreign institutional investors reduce agency costs by enhancing governance and monitoring in emerging markets (Huang \& Zhu, 2015; Aggarwal et al., 2011; Ferreira \& Matos, 2008; Stulz, 2005), corroborating Hypothesis H1.

Briefly commenting on the coefficients fitted for control variables, Tobin's Q, cash flows and dividends are associated to larger cash balances. The positive effect of Tobin's Q is in line with the idea that firms with valuable growth opportunities hold more cash (Han \& Qiu, 2007; Ferreira \& Vilela, 2004). The positive association between cash holdings and cashflows captures firms' financing-cash flow sensitivity, also known as the cashflow sensitivity of cash, and this result seems consistent with the findings reported by Doring et al. (2018) and by Almeida et al. (2004). Dividends are associated to higher cash holdings, in line with Huang et al. (2013) and Chen et al. (2014), but opposing the results reported by Kalcheva \& Lins (2007).

\footnotetext{
${ }^{5}$ Models with Windmeijer standard errors, robust to heteroskedasticity, are also estimated (not reported for brevity), with no material changes in the size of standard errors nor in the statistical significance of coefficients.
} 
Table 4: The effects of foreign institutional ownership on cash holdings

Note: This Table presents estimation results for dynamic panel data cash holdings models, fitted via generalised method of moments (GMM). The models are estimated with firm-year data from 23 emerging markets, collected from Osiris (BVD), covering a sample period of ten years (2006-2015). Cash/Assets is modelled as a function of Cash/Assets lagged by one period, foreign institutional ownership, plus a vector of control variables: Tobin's Q (in logs), investments scaled by total assets, cashflows scaled by total assets, debt scaled by total assets, working capital scaled by total assets and a dividends payment dummy, taking the value of 1 if firms pay dividends, and zero otherwise. Models include year and firm fixed effects (firm effects are wiped out when first-differencing the equation). In the first column, a baseline model with foreign institutional ownership and lagged cash is shown, whilst in the second column the fully fledged model with all control variables is reported. Lagged cash and foreign institutional ownership enter the models as endogenous covariates, instrumented by their own lagged levels, whilst the remaining control variables are instrumented by standard first-differences. Two model specification tests are conducted: Sargan over-identifying restrictions test (with null hypothesis of instrument validity) and Arellano-Bond second order serial correlation test (with null hypothesis of absence of second-order correlation), both shown at the bottom of the table. *** Significant at 0.01 level; ** Significant at 0.05 level; * Significant at 0.1 level.

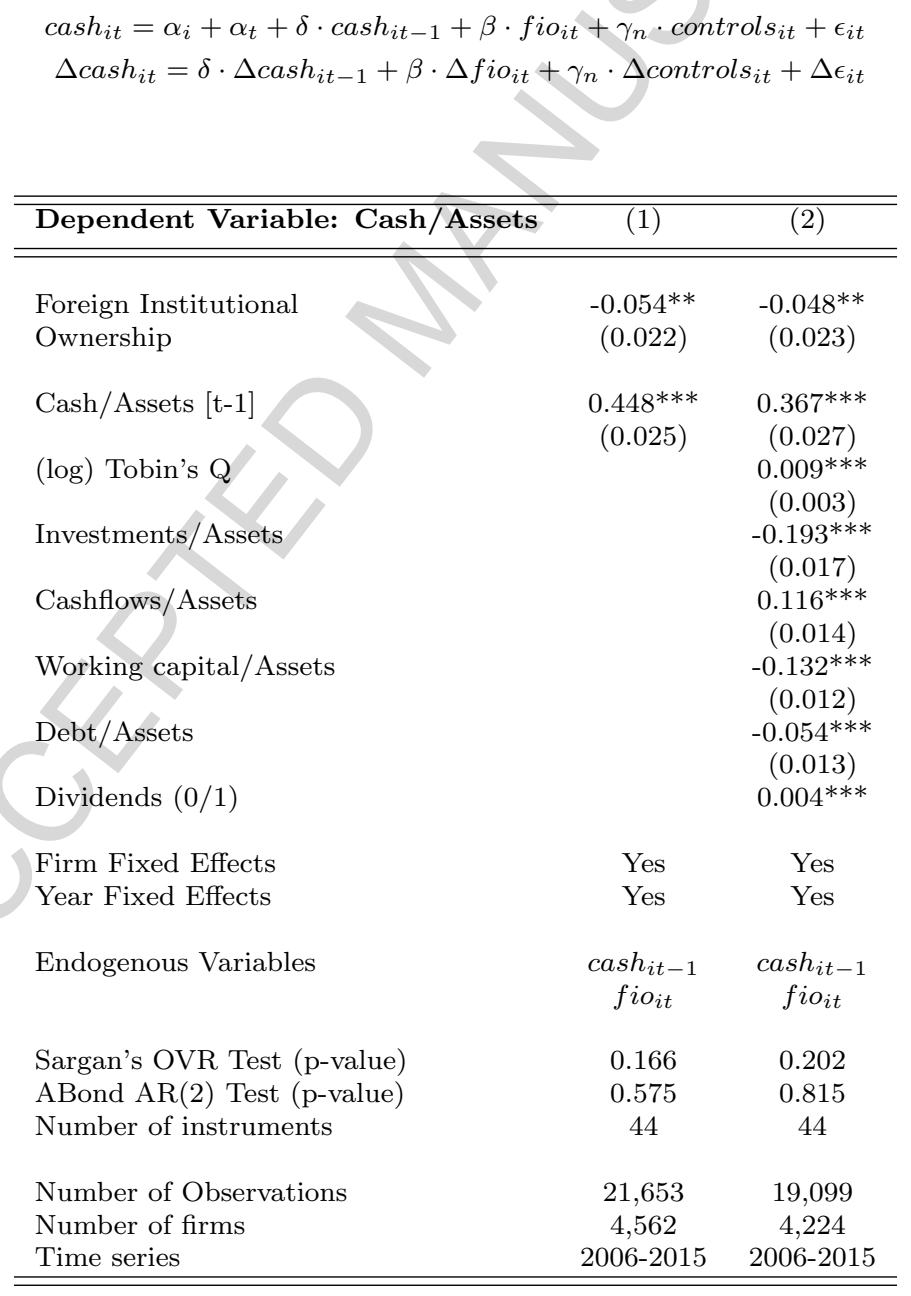


The negative effect of investment on cash is in line with studies reporting that firms with high investments reduce cash, for cash is employed to finance investments (Kalcheva \& Lins, 2007; Huang et al., 2013; Caprio et al., 2013; Chen et al., 2014). Leverage and working capital are associated with lower cash holdings, in line with a trade-off explanation of capital structure and cash holdings decisions (Frank \& Goyal, 2009; Ferreira \& Vilela, 2004; Harris \& Roark, 2018) and with empirical findings reported by Wu et al. (2017); Kalcheva \& Lins (2007); Opler et al. (1999). Regarding model tests, instruments are valid, as the null hypothesis of Sargan's over-identifying restrictions test is accepted, and there is no second-order serial correlation in first-differenced errors, as the null hypothesis of the Arellano-Bond test is accepted.

\subsection{Foreign institutional ownership and the contribution of cash to valuation}

Having shown that foreign institutional ownership marginally reduces corporate cash, this section analyses whether the presence of foreign investors is contributing to enhance the marginal value of corporate cash. Estimation results for firm valuation regressions are shown in Table 5.

As shown in the first column, both cash holdings $\left(0.489^{* * *}\right)$ and foreign institutional ownership $\left(0.202^{* * *}\right)$ load positively, with statistically significant coefficients, on Tobin's Q, suggesting that cash holdings and a higher share of foreign institutional ownership marginally increase corporate valuation ratios. Most importantly, the interaction between foreign ownership and cash is also statistically significant and positive $\left(0.522^{* * *}\right)$, also suggesting that foreign investors augment the valuation of cash holdings.

Considering the interaction with foreign ownership, the partial effect of cash holdings on Tobin's $\mathrm{Q}$ is given by $\hat{\delta}+\hat{\eta} \cdot f \bar{i}_{i t}$. The delta coefficient is the linear partial effect of cash on $\mathrm{Q}(0.489)$, the eta coefficient is the interaction with foreign ownership (0.522), which has to be multiplied by the average value of foreign ownership in the sample (0.10), and this product equals $0.522 \cdot 0.10=0.052$. Therefore, the partial effect of cash on firm valuation is given by $0.489+0.052=0.541$. Whilst a 1 percentage point increase in cash holdings will drive an increase in Tobin's Q of 0.54\%, foreign

\footnotetext{
${ }^{6}$ Logically, an alternative statistical interpretation is that cash holdings enhances the marginal contribution of foreign ownership to corporate valuation, although this alternative view lacks any kind of theoretical support.
} 
Table 5: The effects of foreign institutional ownership on the value of cash

Note: This Table presents estimation results for Tobin's Q (valuation) models, fitted via panel fixed effects regressions. The models are estimated with firm-year data from 23 emerging markets, collected from Osiris (BVD), covering a sample period of ten years (2006-2015). In column (1), Tobin's Q, measured in natural logarithm, and calculated as the market value of equity plus total debt and scaled by total assets, is modelled as a function of cash and cash equivalents scaled by total assets, foreign institutional ownership, an interaction between cash holdings and foreign institutional ownership, plus a vector of control variables: return on equity, investments scaled by total assets, total debt scaled by total assets, dividends, calculated as dummy taking 1 if firms pay dividends, and zero otherwise, and firm size, proxied by the natural logarithm of total assets. In column 2, a similar model design is adopted, with foreign institutional ownership replaced by MSCI constituency, a dummy taking the value of 1 if firms are constituents of MSCI Emerging Markets index, and zero otherwise. Models include year and firm fixed effects, and are estimated with heteroskedasticity-robust standard errors. ${ }^{* * *}$ Significant at 0.01 level; $* *$ Significant at 0.05 level; $*$ Significant at 0.1 level.

$$
(\log ) q_{i t}=\alpha_{i}+\alpha_{t}+\delta \cdot \operatorname{cash}_{i t}+\beta \cdot \text { fio }_{i t}+\eta \cdot \operatorname{cash}_{i t} \cdot \mathrm{fio}_{i t}+\gamma_{n} \cdot \text { controls }_{i t}+\epsilon_{i t}
$$

\begin{tabular}{lcc}
\hline \hline Dependent Variable: (log) Tobin's Q & $(1)$ & $(2)$ \\
\hline \hline & & \\
Cash/Assets & $0.489^{* * *}$ & $0.488^{* * *}$ \\
& $(0.049)$ & $(0.044)$ \\
Foreign Ownership & $0.202^{* * *}$ & \\
& $(0.049)$ & \\
Cash x FIO & $0.522^{* *}$ & \\
MSCI (0/1) & $(0.257)$ & \\
& & $0.184^{* * *}$ \\
Cash x MSCI & & $(0.016)$ \\
& & $0.245^{* * *}$ \\
& & $(0.076)$ \\
Net Income/Equity & & \\
& & \\
(log)Total assets & $0.540^{* * *}$ & $0.533^{* * *}$ \\
Debt/Assets & $(0.019)$ & $(0.019)$ \\
& $-0.106^{* * *}$ & $-0.118^{* * *}$ \\
Investments/Assets & $(0.012)$ & $(0.012)$ \\
& $0.447^{* * *}$ & $0.452^{* * *}$ \\
Dividends (0/1) & $(0.029)$ & $(0.029)$ \\
& $0.638^{* * *}$ & $0.626^{* * *}$ \\
Firm Fixed Effects & $(0.051)$ & $(0.051)$ \\
Year Fixed Effects & $0.020^{* * *}$ & $0.019^{* * *}$ \\
& $(0.006)$ & $(0.006)$ \\
$R^{2}$ & & \\
Number of Observations & Yes & Yes \\
Number of firms & Yes & Yes \\
Time series & 0.832 & 0.835 \\
\hline \hline
\end{tabular}


investors increase the contribution of cash to Tobin's Q by around 10\% (0.052/0.541).

Putting this finding in perspective with those from the previous section, while foreign institutional ownership is associated with reductions in cash holdings, foreign investors are also contributing an important share to increase the contribution of cash to firm valuation. The valuation effect can come from two sides: cash reduction, which liberates resources to other applications, and from discipline instilled by foreign institutional investors on insiders to make a proper use of cash, which can mitigate expropriation risks and hence drive up the value of the firm and of cash.

In the second column, an alternative specification is tested, replacing foreign institutional ownership with MSCI constituency. This is an important test, and attenuates concerns of endogeneity between foreign ownership and Tobin's Q. ${ }^{7}$ MSCI constituency is associated to higher valuations, and the interaction between cash holdings and MSCI is statistically significant and positive.

In light of extant research, results are in line with, and extend prior findings from the cash and governance and the cash and foreign cross-listing literatures. Specifically, previous research has shown that good governance is associated with more efficient cash management, and to higher marginal value of cash (Dittmar \& Mahrt-Smith, 2007; Kalcheva \& Lins, 2007; Pinkowitz et al., 2006; Dittmar et al., 2003). Similar results are also reported in the foreign cross-listing literature, as cross-listing in more developed capital markets, such as in the U.S, exposes emerging markets firms to more stringent governance regimes, enhancing the value of cash (Huang et al., 2013; Fresard \& Salva, 2010). Our findings add a new perspective to the governance-cash value nexus, as it is shown that foreign investors, arguably by instilling better governance, enhance the value of cash in emerging economies, corroborating Hypothesis H2.

\footnotetext{
${ }^{7}$ When estimating the valuation model using MSCI as an instrumental variable for foreign ownership (not reported for brevity), results show that foreign ownership is associated with higher valuations too, though this specification is not appealing in this case because the instrumental variables design makes it complicated to implement the test via interaction of cash and foreign ownership.
} 


\section{Testing the theoretical channels}

\subsection{Investor protection}

We streamline the agency costs channel linking foreign institutional ownership with cash by including in the model a proxy for investor protection, both linearly and interacted with foreign institutional ownership. The linear term captures the direct effect of investor protection on cash holdings, whereas the interaction captures a moderating (mediating) effect, as when investor protection is already high (low), the role of foreign institutions in improving governance loses (gains) importance, therefore a weaker (stronger) effect of foreign institutional ownership on cash holdings is expected. That is, if good governance is lacking, its effect should be stronger where it is scarcer.

To proxy for agency costs, the Minority Investor Protection index calculated by the World Bank is employed. Higher scores signal that countries have stronger investor protection schemes in operation, which reduce the propensity of opportunistic agents to expropriate investors. Scores are converted to a dummy variable, taking the value of 1 for scores above the median, and zero for scores below the median. Tests with similar designs have been previously employed in the cash and governance literature (Kalcheva \& Lins, 2007; Pinkowitz et al., 2006; Dittmar et al., 2003).

Moreover, this test also tackles the issue of heterogeneity across emerging economies. While emerging countries share a number of common characteristics, there could be important differences nonetheless. The interactive term between foreign institutional ownership and investor protection returns an equivalent effect of splitting the sample of countries in two cohorts, grouping more homogeneous countries in terms of institutional quality together. Equation 4 is estimated via static OLS (because investor protection is time-invariant), with results shown in Table 6:

$$
\operatorname{cash}_{i t}=\alpha+\alpha_{j}+\alpha_{t}+\beta \cdot \mathrm{fio}_{i t}+\delta \cdot \operatorname{mip}_{c}+\lambda \cdot \mathrm{fio}_{i t} \cdot \mathrm{mip}_{c}+\gamma_{n} \cdot \text { controls }_{i t}+\epsilon_{i t}
$$

The effect of foreign institutional ownership on corporate cash remains statistically significant and negative, despite controlling for country-level investor protection. Interestingly, in coun- 


\section{Table 6: Effects of investor protection and foreign institutional ownership on cash}

This Table presents estimation results for cash models, fitted via OLS. The models are estimated with firm-year and country data from 23 emerging markets, collected from Osiris (BVD) and World Bank, covering a sample period of ten years (2006-2015). Cash/Assets ratio is modelled as a function of foreign institutional ownership, country-level expropriation risks, proxied by countries' score on the minority investor protection index by World Bank Doing Business Report (higher scores are associated to lower expropriation risk), an interaction between foreign ownership and countrylevel expropriation risk, plus control variables: Tobin's Q (in natural logarithm), Investments/Assets, Cashflows/Assets, Debt/Assets, Working capital/Assets and dividend policy (a dummy taking 1 if firms pay dividends, and zero otherwise). Models include year and industry fixed effects, and are estimated with heteroskedasticity-robust standard errors. *** Significant at 0.01 level; ** Significant at 0.05 level; * Significant at 0.1 level.

\begin{tabular}{|c|c|c|}
\hline Dependent Variable: Cash/Assets & $(1)$ & $(2)$ \\
\hline $\begin{array}{l}\text { Foreign Ownership (FIO) } \\
\text { Investor Protection (MIP) } \\
\text { FIO x MIP }\end{array}$ & $\begin{array}{c}-0.033^{* * *} \\
(0.007) \\
-0.024^{* * *} \\
(0.002)\end{array}$ & $\begin{array}{c}-0.044^{* * *} \\
(0.009) \\
-0.027^{* * *} \\
(0.002) \\
0.032^{* *} \\
(0.014)\end{array}$ \\
\hline $\begin{array}{l}\text { (log) Tobin's Q } \\
\text { Investment/Assets } \\
\text { Cashflow/Assets } \\
\text { Working capital/Assets } \\
\text { Debt/Assets } \\
\text { Dividends }(0 / 1)\end{array}$ & $\begin{array}{c}0.045^{* * *} \\
(0.002) \\
-0.189^{* * *} \\
(0.014) \\
0.230^{* * *} \\
(0.014) \\
-0.125^{* * *} \\
(0.006) \\
-0.097^{* * *} \\
(0.006) \\
0.012^{* * *} \\
(0.002)\end{array}$ & $\begin{array}{c}0.045^{* * *} \\
(0.002) \\
-0.188^{* * *} \\
(0.014) \\
0.230^{* * *} \\
(0.014) \\
-0.125^{* * *} \\
(0.006) \\
-0.096^{* * *} \\
(0.006) \\
0.011^{* * *} \\
(0.002)\end{array}$ \\
\hline $\begin{array}{l}\text { Industry Fixed Effects } \\
\text { Year Fixed Effects }\end{array}$ & $\begin{array}{l}\text { Yes } \\
\text { Yes }\end{array}$ & $\begin{array}{l}\text { Yes } \\
\text { Yes }\end{array}$ \\
\hline $\begin{array}{l}R^{2} \\
\mathrm{~N}\end{array}$ & $\begin{array}{c}0.295 \\
24,939\end{array}$ & $\begin{array}{c}0.295 \\
24,939\end{array}$ \\
\hline
\end{tabular}


tries with stronger investor protection schemes and therefore lower expropriation risk, firms hold marginally less cash. This is consistent with the idea that more stringent governance at countrylevel may discourage opportunistic behaviours by insiders, resulting in lower cash accumulation.

The interaction between foreign institutional ownership and investor protection is statistically significant and positive. The interpretation of this positive interaction is that in countries where investor protection is higher (lower), the effect of foreign institutional ownership on cash holdings is weaker (stronger). In other words, in countries where expropriation of minority investors goes unpunished, the negative effect of foreign institutional ownership on cash holdings is stronger, corroborating the idea that foreign institutions are enhancing surveillance and bringing good governance to poor-governance places, disciplining insiders to accumulate less cash.

\subsection{Analyst coverage and monitoring}

The literature suggests that market analysts play a crucial role in information distribution, intensifying external monitoring (To et al., 2018; Chan \& Hameed, 2006; Irvine, 2003). The greater is the number of brokers providing stock recommendations, more people care about and gain access to the information released by firms and, all else equal, stock price informativeness improves and asymmetric information problems should be mitigated. In line with these evidences, we use analyst coverage as a proxy for monitoring.

Cash is modelled as a function of foreign institutional ownership, plus analyst coverage, and an interaction between analyst coverage and foreign institutional ownership, control variables,

plus industry and year fixed effects. The interaction captures the effect of foreign institutional ownership on cash when monitoring by analysts is already strong. The model shown in Equation 5 is estimated, and results are reported in Table 7:

$$
\operatorname{cash}_{i t}=\alpha+\alpha_{j}+\alpha_{t}+\beta \cdot \text { fio }_{i t}+\delta \cdot \operatorname{acov}_{i}+\lambda \cdot \text { fio }_{i t} \cdot \operatorname{acov}_{i}+\gamma_{n} \cdot \operatorname{controls}_{i t}+\epsilon_{i t}
$$

As shown in the first column of the table, both foreign institutional ownership and analyst 
Table 7: The effects of foreign institutional ownership and monitoring on cash holdings

This Table presents estimation results for cash models, fitted via ordinary least squares. The models are estimated with firm-year data from 23 emerging markets, collected from Osiris (BVD), covering a sample period of ten years (20062015). Cash/Assets ratio is modelled as a function of foreign institutional ownership, analyst coverage (the natural log of total number of brokers providing firms' stock recommendations), an interaction between foreign ownership and analyst coverage, plus control variables: Tobin's Q (in natural logarithm), Investments/Assets, Cashflows/Assets, Debt/Assets, Working capital/Assets and dividend policy (a dummy taking 1 if firms pay dividends, and zero otherwise). Models include year and industry fixed effects, and are estimated with heteroskedasticity-robust standard errors. ${ }^{* *}$ Significant at 0.01 level; ** Significant at 0.05 level; * Significant at 0.1 level.

$$
\operatorname{cash}_{i t}=\alpha+\alpha_{j}+\alpha_{t}+\beta \cdot f i o_{i t}+\delta \cdot \operatorname{acov}_{i}+\lambda \cdot \text { fio }_{i t} \cdot \operatorname{acov}_{i}+\gamma_{n} \cdot \operatorname{controls}_{i t}+\epsilon_{i t}
$$

\begin{tabular}{lcc}
\hline \hline Dependent Variable: Cash/Assets & $(1)$ & $(2)$ \\
\hline \hline & & \\
Foreign Ownership (FIO) & $-0.021^{* *}$ & $-0.068^{* * *}$ \\
& $(0.009)$ & $(0.017)$ \\
(log) Analysts Coverage (ACOV) & $-0.007^{* * *}$ & $-0.009^{* * *}$ \\
& $(0.001)$ & $(0.001)$ \\
FIO x ACOV & & $0.026^{* * *}$ \\
& & $(0.009)$ \\
& & \\
(log) Tobin's Q & $0.050^{* * *}$ & $0.050^{* * *}$ \\
& $(0.003)$ & $(0.003)$ \\
Investments/Assets & $-0.239^{* * *}$ & $-0.239^{* * *}$ \\
& $(0.019)$ & $(0.019)$ \\
Cashflows/Assets & $0.323^{* * *}$ & $0.322^{* * *}$ \\
& $(0.019)$ & $(0.019)$ \\
Working capital/Assets & $-0.155^{* * *}$ & $-0.155^{* * *}$ \\
& $(0.009)$ & $(0.009)$ \\
Debt/Assets & $-0.056^{* * *}$ & $-0.056^{* * *}$ \\
& $(0.008)$ & $(0.008)$ \\
Dividends (0/1) & 0.001 & 0.001 \\
& $(0.002)$ & $(0.002)$ \\
Industry Fixed Effects & & \\
Year Fixed Effects & Yes & Yes \\
$R^{2}$ & Yes & Yes \\
$N$ & & \\
\hline \hline
\end{tabular}


coverage exert a statistically significant and negative effect on corporate cash holdings. The interaction of foreign institutional ownership and analyst coverage loads statistically significantly and positively on corporate cash. The implication is that when monitoring by investment analysts is already relatively higher, the marginal reduction in cash holdings brought about by foreign investors' monitoring is weaker (or conversely, stronger when firms are covered by a smaller number of analysts). The interpretation is that when existing monitoring is high, foreign investors contribute less with enhanced discipline on managers. In other words, foreign investors add more to governance when existing market monitoring is poorer, thus improving monitoring.

\subsection{Financing constraints}

This section tests for the financing constraints channel. In line with the argument developed in the literature section, foreign institutional ownership may help reducing equity financial constraints by making external finance relatively cheaper. In order to assess how foreign institutional ownership may be affecting financing constraints, two tests are conducted.

Financial constraints can be captured by firms' propensity to save cash holdings out of cashflows, also referred to in the literature as the cashflow sensitivity of cash, or the financing-cash flow sensitivity (Almeida et al., 2004; Doring et al., 2018). On the other hand, Khurana et al. (2006) suggest that local financial development reduces firms' cash holdings sensitivity with respect to cashflows. Considering that cross-border finance and the associated influx of foreign investors to emerging economies improves financial development (Rajan \& Zingales, 2003), the first test inspects whether foreign institutional ownership reduces the cashflow sensitivity of cash holdings.

Additional models are estimated, with cash holdings modelled as a function of foreign institutional ownership, plus a dummy equal to 1 for high cashflow firms (with cashflows scaled by assets above the sample's median), and zero otherwise, and plus an interaction between foreign institutional ownership and the high cashflows dummy, which captures the effect of foreign institutional ownership on firms' propensity to save cash holdings out of cashflows. Equation 6 is estimated: 


$$
\operatorname{cash}_{i t}=\alpha+\alpha_{j}+\alpha_{t}+\beta \cdot f i o_{i t}+\gamma \cdot C F_{i t}+\eta \cdot f i o_{i t} \cdot C F_{i t}+\lambda \cdot \text { controls }_{i t}+\epsilon_{i t}
$$

Second, as smaller firms are more likely to be financially constrained (for they have lower access to external finance and lower collateral to offer in debt contracts) and therefore tend to hold more cash, it is tested whether foreign institutional ownership reduces the sensitivity of cash holdings with respect to firm size. Cash is modelled as a function of foreign institutional ownership, plus a dummy equal to one for small firms and zero for large firms (small firms with total assets below sample's median), and plus an interaction between foreign institutional ownership and firm size, which captures the effect of foreign institutional ownership on small firms' propensity to save cash out of cashflows. Equation 7 is also estimated:

$$
\operatorname{cash}_{i t}=\alpha+\alpha_{j}+\alpha_{t}+\beta \cdot \text { fio }_{i t}+\gamma \cdot \operatorname{Small}_{i t}+\eta \cdot \mathrm{fio}_{i t} \cdot \operatorname{Small}_{i t}+\lambda \cdot \text { controls }_{i t}+\epsilon_{i t}
$$

Table 8 reports the results. As shown in column (1), higher cashflow generation is associated to higher propensity to save cash. As reported in column (2), given the negative and statistically significant interaction between cashflows and foreign institutional ownership, foreign institutions reduce the propensity of firms to accumulate cash holdings out of internally generated cashflows.

Findings reported in Columns (3) and (4) show that small firms hold more cash when compared to large firms, corroborating the idea that smaller firms tend to be relatively more financially constrained. More interestingly, the negative interaction between small firms and foreign institutional ownership suggests that foreign institutions may reduce the sensitivity of cash holdings to firm size. Taken these findings on the effect of foreign institutional ownership on the sensitivity of cash holdings to both cashflows and firm size altogether, empirical evidence is aligned with the idea that foreign institutional ownership alleviates financing constraints. 
Table 8: The effect of foreign institutional ownership on financing constraints

This Table presents estimation results for cash holdings models, fitted via ordinary least squares. The models are estimated with firm-year data from 23 emerging markets, collected from Osiris (BVD), covering a sample period of ten years (2006-2015). In columns (1) and (2), cash ratio is modelled as a function of foreign institutional ownership, a dummy for high cashflows firms, taking one for firms with cashflows scaled by assets above the median, and zero otherwise, plus an interaction between foreign institutional ownership and high cashflow firms, with the interaction capturing the effect of foreign institutional ownership on the cashflow sensitivity of cash holdings. In columns (3) and (4), cash ratio is modelled as a function of foreign institutional ownership, a dummy for firm size, taking the value of one for firms with total assets below the median, and zero otherwise (small $=1$, large $=0$ ), plus an interaction between foreign institutional ownership and the dummy for small firms, capturing the effect of foreign institutional ownership on the size sensitivity of cash holdings. Control variables include: Tobin's Q (in natural log), Investments/Assets, Cashflows/Assets, Debt/Assets, Working capital/Assets and dividend policy (a dummy taking 1 if firms pay dividends, and zero otherwise). Models include year and industry fixed effects, and are estimated with heteroskedasticity-robust standard errors. ${ }^{* * *}$ Significant at 0.01 level; ** Significant at 0.05 level; * Significant at 0.1 level..

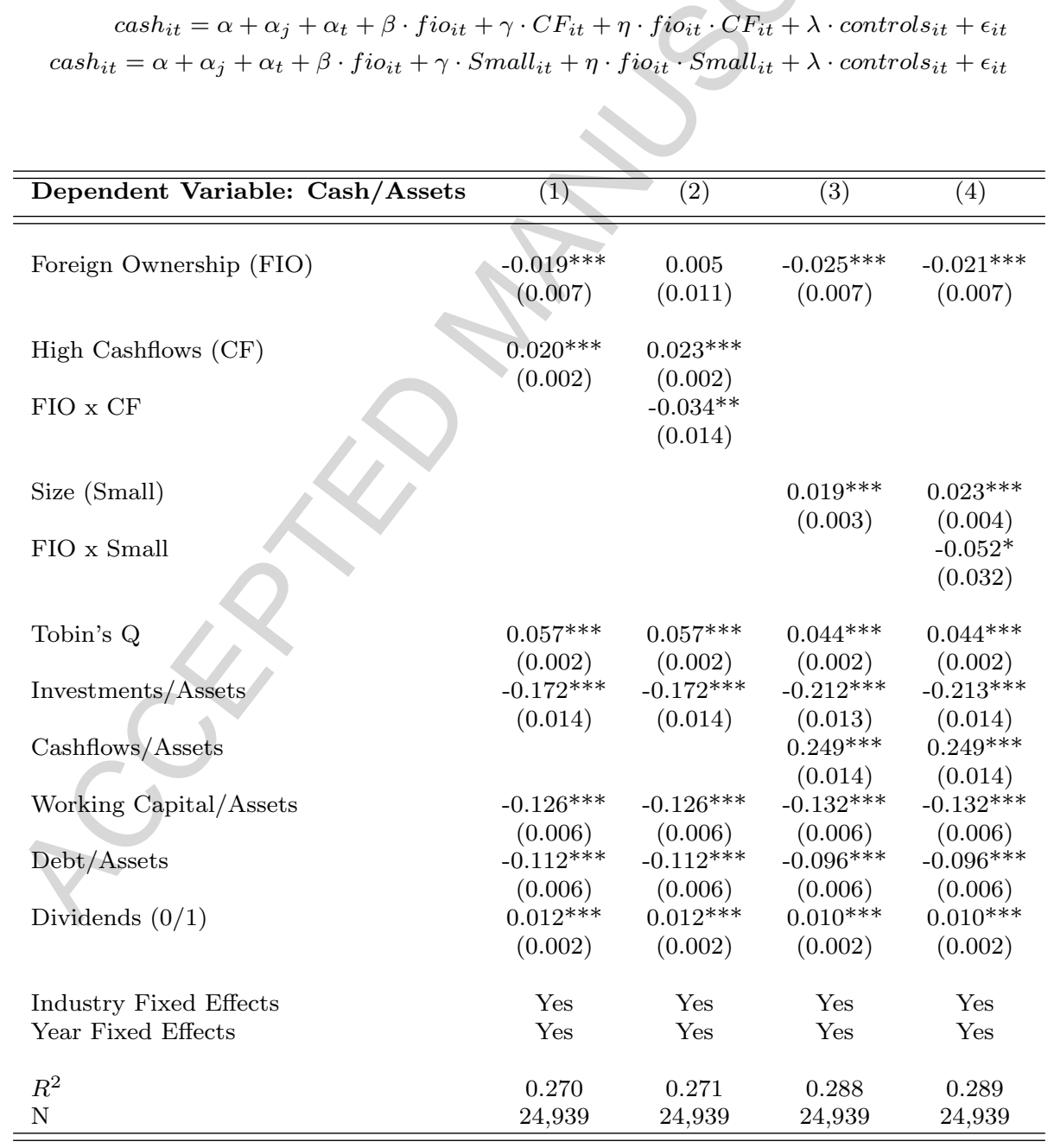




\section{Robustness checks}

\subsection{Instrumental variables}

While foreign institutional ownership is modelled as an endogenous covariate in the dynamic cash model shown in the Results section, instrumental variables models can further contribute to an even cleaner identification. To put more structure on the reliability of econometric results, cash holdings models are again estimated, this time via instrumental variables GMM regressions.

MSCI Constituency serves as instrumental variable $\left(z_{i t}\right)$ capturing exogenous variation in foreign institutional ownership, following a widely employed practice in the foreign institutional ownership literature (Bena et al., 2017; Hillier \& Loncan, 2017; Aggarwal et al., 2011). This variable is calculated as dummy, taking the value of 1 if the firm is a constituent of MSCI Emerging Markets Index, and zero otherwise, tracking both additions and deletions over time, being statistically correlated with foreign ownership $(0.24, p<0.01)$. Equation 8 is estimated:

$$
(\log ) \operatorname{cash}_{i t}=\alpha_{i}+\alpha_{t}+\beta \cdot\left[z_{i t}\right](\log ) \text { fio }_{i t}+\gamma_{n} \cdot \text { controls }_{i t}+\epsilon_{i t}
$$

In the first column, First-stage results are shown. MSCI constituency is statistically and positively associated to marginal increases in foreign stock ownership $\left(0.09^{* * *}\right)$, being thus a relevant instrument. In the second column, Second-stage results are reported. Foreign ownership, as instrumented by MSCI Constituency, marginally reduces cash holdings $\left(-0.763^{* *}\right)$, and this effect is statistically significant at 95\% confidence level. Kleibergen-Paap under-identification and weakidentification tests suggest strong identification in the IV model, as both null hypotheses of under and weak identification of instruments are rejected. This result, again, supports Hypothesis H1, corroborating the idea that the influx of foreign investors reduces firms' incentives to hold cash. 
Table 9: Instrumental variables model

This Table presents estimation results for cash models, fitted via two-stages instrumental variables regressions (GMM). The models are estimated with firm-year data from 23 emerging markets, collected from Osiris (BVD), covering a sample period of ten years (2006-2015). Cash/Assets (in natural logarithm) is modelled as a function of foreign institutional ownership (in natural logarithm), instrumented by MSCI constituency $\left(z_{i t}\right)$, a dummy taking the value of 1 if firms are constituents of MSCI Emerging Markets index, and zero otherwise, plus a vector of control variables: Tobin's Q (in natural logarithm), investments scaled by total assets, cashflows scaled by total assets, total debt scaled by total assets, working capital scaled by total assets, and dividends, calculated as a dummy taking the value of 1 if firms pay dividends, and zero otherwise. Models include year and firm fixed effects, and are estimated with heteroskedasticityrobust standard errors. In column (1), first-stage results are reported, whilst column (2) shows second-stage results. The strength of instrumental variables is tested by the Kleibergen-Paap under-identification and weak-identification tests (both tests with null hypotheses of under and weak identification), shown at the bottom of the table. ${ }^{* * *}$ Significant at 0.01 level; ** Significant at 0.05 level; * Significant at 0.1 level.

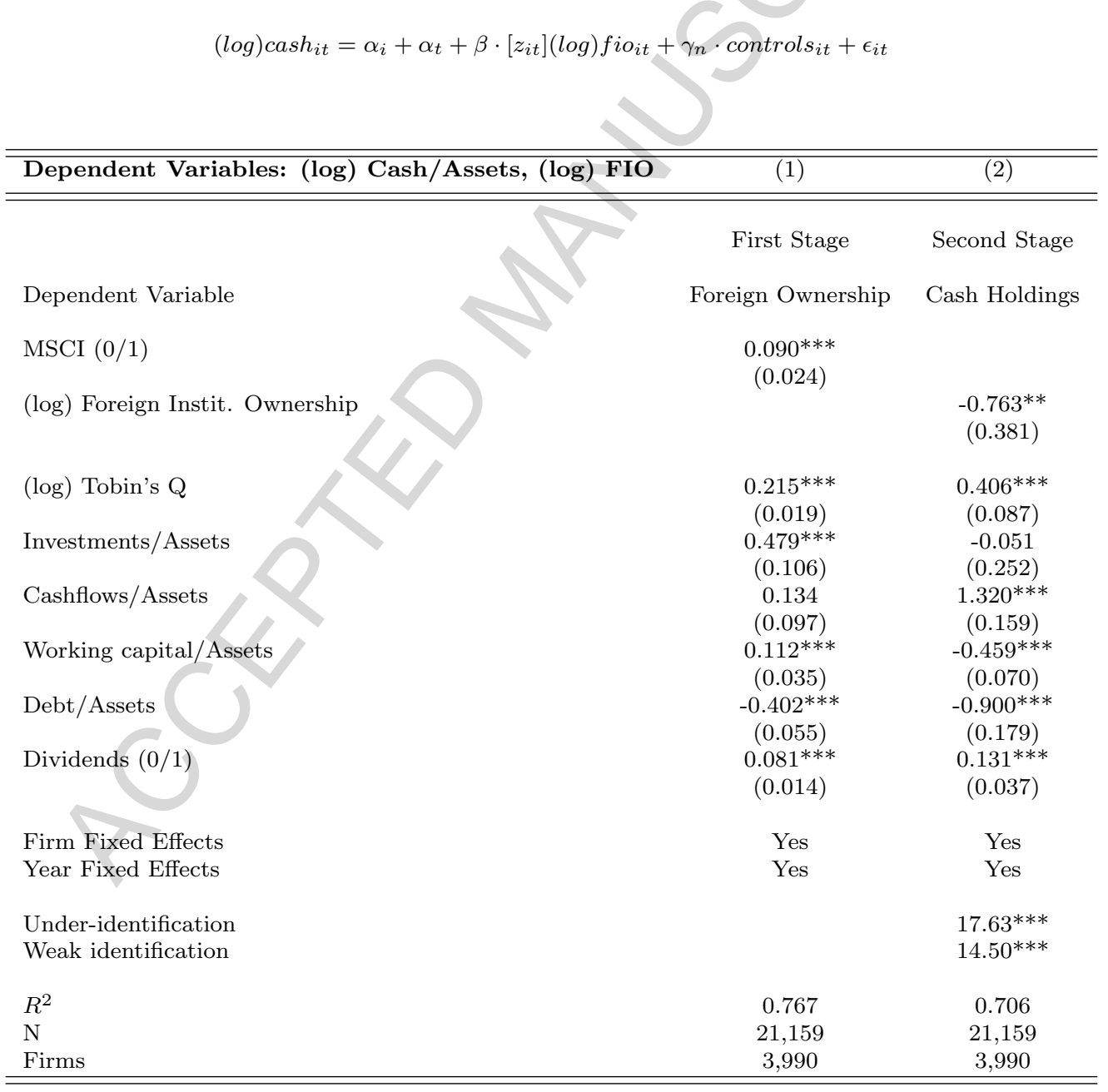




\subsection{The effect of country-level stock market liberalisation on firm-level cash holdings}

In this section, a measure of country-level capital inflow liberalisation is employed as proxy for the influx of foreign investors, drawn from the IMF (International Monetary Fund) database. 8 The capital inflow liberalisation index captures openness to foreign capital flows $\left(l i b_{c t}\right)$, calculated by Jahan \& Wang (2016). This index runs between [0,1], with higher scores associated to lower barriers to the free inflow of foreign investments in equities and bonds.

Given country-level data is exogenous to individual firms' characteristics by construction, such liberalisation measure contributes with cleaning identification again. 9 The model shown in Equation 9 is estimated, and estimation results are reported in Table 10:

$$
\operatorname{cash}_{i t}=\alpha+\alpha_{j}+\alpha_{t}+\alpha_{c}+\beta \cdot \operatorname{lib}_{c t}+\gamma_{n} \cdot \text { controls }_{i t}+\epsilon_{i t}
$$

Results reported in the first column show that firms located in countries obtaining a higher score in the liberalisation index hold marginally less cash $\left(-0.022^{* * *}\right)$, suggesting that liberalisation affects firms' cash policy. In the second column, another model is estimated, this time wiping out country fixed effects, such that the effect of liberalisation is not influenced by countries' unobserved heterogeneity, and results remain materially unchanged. Crucially, putting this analysis in perspective with the previous results shown in the paper, qualitatively similar effects on cash holdings (reductions) are obtained when using both firm-level (foreign institutional ownership) and country-level (liberalisation) variables capturing foreign investors activity in the market.

Whilst a number of papers show that stock market liberalisation reduces cost of equity capital (Henry, 2000b; Bekaert \& Harvey, 2000; Patro \& Wald, 2005; Christoffersen et al., 2006), other strands of literature report that liberalisation induces investment booms, productivity gains and

\footnotetext{
${ }^{8}$ Because country liberalisation and capital flows estimates are unavailable, firms from Taiwan are dropped from this analysis.

${ }^{9}$ In line with the idea that country-level liberalisation is associated to a higher presence of foreign investors, country-level foreign institutional ownership and the capital inflow liberalisation index are positively and statistically significantly correlated, and liberalisation at the country-level and cash holdings at the firm-level are statistically and negatively correlated too.
} 
Table 10: The effect of country-level market liberalisation on firm-level cash holdings

This Table presents estimation results for cash models, fitted via OLS regressions. The models are estimated with firmyear and country-year data from 22 emerging markets, collected from Osiris (BVD) and the IMF, covering a sample period of ten years (2006-2015). In the model shown in column (1), Cash/Assets ratio is modelled as a function of countries' capital inflow liberalisation, an index ranging between $[0,1]$, with higher scores associated to countries with more liberalised markets. Models include a vector of control variables: Tobin's Q (in natural logarithm), Investments/Assets, Cashflows/Assets, Debt/Assets, Working capital/Assets and dividend policy (a dummy taking 1 if firms pay dividends, and zero otherwise), year and industry fixed effects (the model in column 2 also includes country fixed effects). Models are estimated with heteroskedasticity-robust standard errors. ${ }^{* * *}$ Significant at 0.01 level; ** Significant at 0.05 level; * Significant at 0.1 level.

\begin{tabular}{|c|c|c|}
\hline Dependent Variable: Cash/Assets & (1) & $(2)$ \\
\hline Liberalisation $[0,1]$ & $\begin{array}{c}-0.022^{* *} \\
(0.009)\end{array}$ & $\begin{array}{c}-0.021^{* *} \\
(0.009)\end{array}$ \\
\hline (log) Tobin's Q & $\begin{array}{c}0.042^{* * *} \\
(0.002)\end{array}$ & $\begin{array}{c}0.042^{* * *} \\
(0.002)\end{array}$ \\
\hline Investment/Asset & $\begin{array}{c}-0.140^{* * *} \\
(0.014)\end{array}$ & $\begin{array}{c}-0.117^{* * * *} \\
(0.014)\end{array}$ \\
\hline Cashflow/Assets & $\begin{array}{c}0.210^{* * *} \\
(0.014)\end{array}$ & $\begin{array}{c}0.212^{* * * *} \\
(0.014)\end{array}$ \\
\hline Working capital/Assets & $\begin{array}{c}-0.076^{* * *} \\
(0.007)\end{array}$ & $\begin{array}{c}-0.083^{* * *} \\
(0.007)\end{array}$ \\
\hline & $\begin{array}{c}-0.059^{* * *} \\
(0.006)\end{array}$ & $\begin{array}{c}-0.069 * * * \\
(0.006)\end{array}$ \\
\hline Dividends (0/1) & $\begin{array}{c}0.004^{* *} \\
(0.002)\end{array}$ & $\begin{array}{c}0.006^{* * *} \\
(0.002)\end{array}$ \\
\hline Industry fixed effects & Yes & Yes \\
\hline Year fixed effects & Yes & Yes \\
\hline Country fixed effects & No & Yes \\
\hline$R^{2}$ & 0.237 & 0.310 \\
\hline $\mathrm{N}$ & 20,212 & 20,206 \\
\hline Firms & 3,485 & 3,485 \\
\hline
\end{tabular}


economic growth (Henry, 2000a; Bekaert et al., 2005; Chari \& Henry, 2008; Quinn \& Toyoda, 2008; Bonfiglioli, 2008; Bekaert et al., 2011; Larrain \& Stumpner, 2017). The findings from the analysis of country-level liberalisation effects on cash holdings contribute new evidence to the current-account liberalisation literature, by showing that liberalisation affects not only cost of capital, investment and productivity, also affecting cash holdings policy.

\subsection{Foreign invested versus strictly domestically invested firms}

In our core analysis we dropped those firms with zero or irrelevant foreign institutional ownership. However, it is interesting to see if foreign-invested firms also hold less cash when compared to strictly domestically-invested firms. In this section we analyse this possibility.

We separate foreign-invested from domestically-invested firms employing a dummy, fio $o_{i t}^{D}$, equal to 1 for firms with foreign institutional ownership greater than zero, and equal to zero otherwise. In this setup, many firms are brought back to the analysis, allowing estimating models with a much larger sample. As another additional sensitivity check, we use a different proxy for agency costs, employing the Anti-corruption index, sourced from International Country Risk Guide, adding robustness to the the agency costs channel test. Equation 10 is estimated:

$$
\operatorname{cash}_{i t}=\alpha+\alpha_{j}+\alpha_{t}+\beta \cdot \text { fio }_{i t}^{D}+\delta \cdot \text { anticorrup }_{c t}+\lambda \cdot \text { fio }_{i t}^{D} \cdot \text { anticorrupt }_{c t}+\epsilon_{i t}
$$

Table 11 shows the results. The dummy distinguishing foreign invested from strictly domestically invested firms is significant and negative. Therefore, foreign invested firms accumulate less cash than strictly domestically invested firms. While firms hold less cash in less corrupt countries, the interaction between the foreign/domestic dummy and the Anti-corruption index is significant and positive, hence foreign institutions exert weaker effects when corruption is lower.

In column 3, we analyse whether the effect of foreign institutional ownership on cash holdings has changed over time. We code a dummy, splitting our sampling period in two equal sub-periods of 5 years each. This dummy is named Post 2010, and equals 1 for the years after 2010 (2011-2015), 
Table 11: Foreign invested versus strictly domestically invested firms

This Table presents estimation results. Models are estimated with data from 23 emerging markets, collected from Osiris (BVD), covering a sample period of ten years (2006-2015). Cash/Assets ratio is modelled as a function of foreign institutional ownership (measured as a dummy, equal to 1 for firms with foreign institutional ownership greater than zero, and equal to zero otherwise), country-level agency costs, proxied by countries' score on the anti-corruption index from International Country Risk Guide (higher the score, lower is corruption), an interaction between foreign ownership and anti-corruption, plus control variables: Tobin's Q (in natural logarithm), Investments/Assets, Cashflows/Assets, Debt/Assets, Working capital/Assets and dividend policy (a dummy taking 1 if firms pay dividends, and zero otherwise). Models include year and industry fixed effects, and are estimated with heteroskedasticity-robust standard errors. ${ }^{* * *}$ Significant at 0.01 level; ** Significant at 0.05 level; * Significant at 0.1 level.

$\operatorname{cash}_{i t}=\alpha+\alpha_{j}+\alpha_{t}+\beta \cdot$ fio $_{i t}^{D}+\delta \cdot$ anticorrup $_{c t}+\lambda \cdot$ fio $_{i t}^{D} \cdot$ anticorrupt $_{c t}+\epsilon_{i t}$

\begin{tabular}{lccc}
\hline \hline Dependent Variable: Cash/Assets & $(1)$ & $(2)$ & $(3)$ \\
\hline \hline & & & \\
Foreign Owership (Dummy) & $-0.005^{* * *}$ & $-0.004^{* * *}$ & $-0.003^{* *}$ \\
& $(0.001)$ & $(0.001)$ & $(0.001)$ \\
Anti-corruption Index (Anticorrup) & & $-0.015^{* * *}$ & $-0.015^{* * *}$ \\
& & $(0.001)$ & $(0.001)$ \\
FIO x Anticorrupt & & $0.004^{* * *}$ & $0.005^{* * *}$ \\
& & $(0.002)$ & $(0.002)$ \\
FIO x Post 2010 & & $-0.003^{*}$ \\
& & & $(0.002)$ \\
(log) Tobin's Q & & & \\
& $0.040^{* * *}$ & $0.040^{* * *}$ & $0.040^{* * *}$ \\
Investment/Assets & $(0.001)$ & $(0.001)$ & $(0.001)$ \\
& $-0.164^{* * *}$ & $-0.165^{* * *}$ & $-0.165^{* * *}$ \\
Cashflow/Assets & $(0.007)$ & $(0.007)$ & $(0.007)$ \\
& $0.142^{* * *}$ & $0.136^{* * *}$ & $0.136^{* * *}$ \\
Working capital/Assets & $(0.006)$ & $(0.006)$ & $(0.006)$ \\
& $-0.102^{* * *}$ & $-0.102^{* * *}$ & $-0.102^{* * *}$ \\
Debt/Assets & $(0.003)$ & $(0.003)$ & $(0.003)$ \\
& $-0.176^{* * *}$ & $-0.177^{* * *}$ & $-0.177^{* * *}$ \\
Dividends (0/1) & $(0.003)$ & $(0.003)$ & $(0.003)$ \\
& $0.017^{* * *}$ & $0.019^{* * *}$ & $0.019^{* * *}$ \\
& $(0.001)$ & $(0.001)$ & $(0.001)$ \\
Industry Fixed Effects & & & \\
Year Fixed Effects & Yes & Yes & Yes \\
& Yes & Yes & Yes \\
$R^{2}$ & & & \\
$\mathrm{~N}$ & 0.246 & 0.248 & 0.248 \\
\hline \hline
\end{tabular}


and equals zero for the years before and including 2010 (2006-2010). We interact this variable with foreign institutional ownership (FIO x Post 2010). This interaction captures the change in the effect of foreign institutional ownership on cash holdings in the most recent sampling period (20112015) as opposed to the initial sampling period (2006-2010). The interaction resulted significant and negative, suggesting the effect may be time-varying and possibly became stronger over time.

\section{Conclusions}

This paper investigates the effect of foreign institutional ownership on cash holdings. It is hypothesised that foreign institutional ownership, by mitigating agency costs and by lowering external finance cost, reduces firms' propensity to accumulate cash. Moreover, by disciplining managers to stick to efficient cash levels and by preventing expropriation, it is also hypothesised that foreign institutional ownership increases the contribution of cash to firm valuation.

These hypotheses are empirically tested for a sample of firms from 23 emerging economies. Results show that, as hypothesised, a larger share of foreign institutional ownership is associated to marginal reductions in corporate cash holdings. Moreover, foreign institutional ownership drives a premium on the marginal value of cash, consistent with the idea that foreign investors contribute to a more efficient, value-enhancing and trustworthy corporate cash management.

By inspecting a number of theoretical mechanisms, we further provide empirical evidence consistent with our hypotheses that mitigation of agency conflicts and reduction of external finance costs are two important channels linking foreign institutional ownership to cash holdings. Moreover, our results are robust to a number of sensitivity checks. Particular attention is given to identification issues. Models fitted via dynamic panel GMM, instrumental variables and regressions employing country-level liberalisation measures all yielded consistent results, robust to endogeneity concerns.

The findings from our paper have important economic implications, and also contribute relevant insights to the finance literature. In terms of economic effects, our results suggest that foreign institutional investors are pushing firms towards a more efficient and rational cash management. As a result of reductions in the levels of cash holdings, more economic resources become available to 
be allocated in other activities which can contribute to firms' growth, such as corporate investments. Moreover, by deterring cash expropriation via enhanced governance, foreign investors prevent the dissipation of valuable economic resources which rightfully belong to firms and their shareholders, contributing to a better economic and institutional environment in emerging economies.

In addition, foreign institutions are also shown to create economic value to firms by increasing the marginal value of cash as priced in the stock market by investors. That is, through enhanced governance, foreign institutional investors seem to be contributing to increase the valuation of firms. This financial effect can spillover to real economic output as well. For instance, a higher valuation can reduce the cost of equity capital, which can allow firms to invest even more.

With respect to our contributions to the academic debate in this area, while existing studies suggest that foreign institutions create value via lowering cost of capital and by increasing investments and innovations, our findings complement and extend prior studies by adding a financing structure perspective, as we demonstrate that foreign institutions also exert beneficial effects on firms' cash management. In all, putting our results in perspective with the extant literature, foreign institutional investors seem to contribute towards optimising the allocation balance between financial and productive capital within invested firms. This adds to the notion currently advocated in the literature that foreign institutions enhance corporate managerial decisions.

The paper has a number of limitations, though. The analysis falls short of a firm-specific internal measure of expected agency costs, other than foreign institutional ownership, such as governance and board data. The sample studied includes emerging economies, but leaves out other relevant countries, in particular frontier markets. The analysis neglects other financing choices, in particular leverage. In fact, implications of foreign institutional ownership and of financial liberalisation to firms' capital structure seems an interesting research avenue for papers to come.

While acknowledging such limitations, the paper adds new evidence on the pros and cons of the ever increasing presence of foreign investors in emerging economies, with results suggesting beneficial effects of foreign institutions on corporate managerial decisions of emerging market firms, reflected in more efficient and value-enhancing cash policies. 


\section{Acknowledgements}

The author is grateful for comments and discussions from participants at the INFINITI International Finance Conference (Poznan, Poland), and at the British Accounting and Finance Association conference (London, United Kingdom). I am particularly indebted to Tjeerd Boonman, Charlie Cai, Khaled Hussainey and two anonymous reviewers for comments which helped improving the paper. Any eventual errors are my own.

\section{References}

Acharya, Viral V., Almeida, Heitor, \& Campello, Murillo. 2007. Is cash negative debt? a hedging perspective on corporate financial policies. Journal of financial intermediation, 16(4), 515-554.

Aggarwal, Reena, Erel, Isil, Ferreira, Miguel, \& Matos, Pedro. 2011. Does governance travel around the world? Evidence from institutional investors. Journal of financial economics, 100(1), 154181.

Almeida, Heitor, Campello, Murillo, \& Weisbach, Michael S. 2004. The Cash Flow Sensitivity of Cash. Journal of finance, 59(4), 1777-1804.

Altinkilic, Oya, \& Hansen, Robert S. 2000. Are There Economies of Scale in Underwriting Fees? Evidence of Rising External Financing Costs. Review of financial studies, 13(1), 191-218.

Altinkilic, Oya, \& Hansen, Robert S. 2003. Discounting and underpricing in seasoned equity offers. Journal of financial economics, 69(2), 285-323.

Amess, Kevin, Banerji, Sanjay, \& Lampousis, Athanasios. 2015. Corporate cash holdings: Causes and consequences. International review of financial analysis, 42(C), 421-433.

Anderson, T. W., \& Hsiao, Cheng. 1981. Estimation of Dynamic Models with Error Components. Journal of the american statistical association, 76(375), 598-606. 
Arellano, Manuel, \& Bond, Stephen. 1991. Some Tests of Specification for Panel Data: Monte Carlo Evidence and an Application to Employment Equations. Review of economic studies, 58(2), 277-297.

Baltagi, Badi H., Demetriades, Panicos O., \& Law, Siong Hook. 2009. Financial development and openness: Evidence from panel data. Journal of development economics, 89(2), 285-296.

Bekaert, Geert, \& Harvey, Campbell R. 2000. Foreign Speculators and Emerging Equity Markets. Journal of finance, 55(2), 565-613.

Bekaert, Geert, Harvey, Campbell R., \& Lundblad, Christian. 2005. Does financial liberalization spur growth? Journal of financial economics, 77(1), 3-55.

Bekaert, Geert, Harvey, Campbell R., \& Lundblad, Christian. 2011. Financial Openness and Productivity. World development, 39(1), 1-19.

Bena, Jan, Ferreira, Miguel A, Matos, Pedro, \& Pires, Pedro. 2017. Are foreign investors locusts? The long-term effects of foreign institutional ownership. Journal of financial economics.

Bonfiglioli, Alessandra. 2008. Financial integration, productivity and capital accumulation. Journal of international economics, $\mathbf{7 6}(2), 337-355$.

Caprio, Lorenzo, Faccio, Mara, \& McConnell, John J. 2013. Sheltering Corporate Assets from Political Extraction. Journal of law, economics and organization, 29(2), 332-354.

Chan, Kalok, \& Hameed, Allaudeen. 2006. Stock price synchronicity and analyst coverage in emerging markets. Journal of financial economics, 80(1), 115-147.

Chari, Anusha, \& Henry, Peter Blair. 2004. Risk Sharing and Asset Prices: Evidence from a Natural Experiment. Journal of finance, 59(3), 1295-1324.

Chari, Anusha, \& Henry, Peter Blair. 2008. Firm-specific information and the efficiency of investment. Journal of financial economics, 87(3), 636-655. 
Chen, Deqiu, Li, Sifei, Xiao, Jason Zezhong, \& Zou, Hong. 2014. The effect of government quality on corporate cash holdings. Journal of corporate finance, 27(C), 384-400.

Christoffersen, Peter, Chung, Hyunchul, \& Errunza, Vihang. 2006. Size matters: The impact of financial liberalization on individual firms. Journal of international money and finance, 25(8), 1296-1318.

Corwin, Shane A. 2003. The Determinants of Underpricing for Seasoned Equity Offers. Journal of finance, 58(5), 2249-2279.

Dahlquist, Magnus, \& Robertsson, Goran. 2001. Direct foreign ownership, institutional investors, and firm characteristics. Journal of financial economics, 59(3), 413-440.

Deng, Baijun, Li, Zhongfei, \& Li, Yong. 2018. Foreign institutional ownership and liquidity commonality around the world. Journal of corporate finance, 51, $20-49$.

Dittmar, Amy, \& Mahrt-Smith, Jan. 2007. Corporate governance and the value of cash holdings. Journal of financial economics, 83(3), 599-634.

Dittmar, Amy, Mahrt-Smith, Jan, \& Servaes, Henri. 2003. International Corporate Governance and Corporate Cash Holdings. Journal of financial and quantitative analysis, 38(01), 111-133.

D’Mello, Ranjan, Krishnaswami, Sudha, \& Larkin, Patrick J. 2008. Determinants of corporate cash holdings: Evidence from spin-offs. Journal of banking 8 finance, 32(7), 1209-1220.

Doidge, Craig, Karolyi, G. Andrew, \& Stulz, Rene M. 2004. Why are foreign firms listed in the U.S. worth more? Journal of financial economics, 71(2), 205-238.

Doring, Simon, Drobetz, Wolfgang, Janzen, Malte, \& Meier, Iwan. 2018. Global cash flow sensitivities. Finance research letters, 25, $16-22$.

Ferreira, Miguel A., \& Matos, Pedro. 2008. The colors of investors' money: The role of institutional investors around the world. Journal of financial economics, 88(3), 499-533. 
Ferreira, Miguel A., \& Vilela, Antonio S. 2004. Why do firms hold cash? evidence from emu countries. European financial management, 10(2), 295-319.

Frank, Murray Z., \& Goyal, Vidhan K. 2009. Capital structure decisions: Which factors are reliably important? Financial management, 38(1), 1-37.

Fresard, Laurent, \& Salva, Carolina. 2010. The value of excess cash and corporate governance: evidence from U.S. cross-listings. Journal of financial economics, 98(2), 359-384.

Gamba, Andrea, \& Triantis, Alexander. 2008. The Value of Financial Flexibility. Journal of finance, 63(5), 2263-2296.

Greene, William H. 2012. Econometric Analysis. 7 edn. Pearson Education Limited.

Han, Seungjin, \& Qiu, Jiaping. 2007. Corporate precautionary cash holdings. Journal of corporate finance, 13(1), 43-57.

Harris, Christopher, \& Roark, Scott. 2018. Cash flow risk and capital structure decisions. Finance research letters.

Harris, Milton, \& Raviv, Artur. 2017. Why Do Firms Sit on Cash? An Asymmetric Information Approach. Review of corporate finance studies, 6(2), 141-173.

Henry, Peter Blair. 2000a. Do stock market liberalizations cause investment booms? Journal of financial economics, 58(1-2), 301-334.

Henry, Peter Blair. 2000b. Stock Market Liberalization, Economic Reform, and Emerging Market Equity Prices. Journal of finance, 55(2), 529-564.

Hillier, David, \& Loncan, Tiago. 2017. Stock market integration, cost of equity capital and corporate investment: Evidence from Brazil. European Financial Management, 1 -26.

Huang, Wei, \& Zhu, Tao. 2015. Foreign institutional investors and corporate governance in emerging markets: Evidence of a split-share structure reform in China. Journal of corporate finance, 32(C), 312-326. 
Huang, Ying, Elkinawy, Susan, \& Jain, Pankaj K. 2013. Investor protection and cash holdings: Evidence from US cross-listing. Journal of banking \& finance, 37(3), 937-951.

Irvine, Paul J. 2003. The incremental impact of analyst initiation of coverage. Journal of corporate finance, 9(4), 431-451.

Jahan, Sarwat, \& Wang, Daili. 2016 (Dec.). Capital Account Openness in Low-income Developing Countries; Evidence from a New Database. IMF Working Papers 16/252. International Monetary Fund.

Kalcheva, Ivalina, \& Lins, Karl V. 2007. International Evidence on Cash Holdings and Expected Managerial Agency Problems. Review of financial studies, 20(4), 1087-1112.

Khurana, Inder K., Martin, Xiumin, \& Pereira, Raynolde. 2006. Financial Development and the Cash Flow Sensitivity of Cash. Journal of financial and quantitative analysis, 41(04), 787-808.

Laeven, Luc. 2003. Does financial liberalization reduce financing constraints? Financial management, 31(4).

Lang, Larry H P, \& Stulz, Rene M. 1994. Tobin's q, Corporate Diversification, and Firm Performance. Journal of political economy, 102(6), 1248-1280.

Larrain, Mauricio, \& Stumpner, Sebastian. 2017. Capital account liberalization and aggregate productivity: The role of firm capital allocation. Journal of finance.

Lins, Karl V. 2003. Equity Ownership and Firm Value in Emerging Markets. Journal of financial and quantitative analysis, 38(01), 159-184.

Luong, Hoang, Moshirian, Fariborz, Nguyen, Lily, Tian, Xuan, \& Zhang, Bohui. 2017. How Do Foreign Institutional Investors Enhance Firm Innovation? Journal of financial and quantitative analysis, 52(04), 1449-1490.

Nikolov, Boris, \& Whited, Toni M. 2014. Agency Conflicts and Cash: Estimates from a Dynamic Model. Journal of finance, 69(5), 1883-1921. 
Opler, Tim, Pinkowitz, Lee, Stulz, Rene, \& Williamson, Rohan. 1999. The determinants and implications of corporate cash holdings. Journal of financial economics, 52(1), 3-46.

Ozkan, Aydin, \& Ozkan, Neslihan. 2004. Corporate cash holdings: An empirical investigation of uk companies. Journal of banking \& finance, 28(9), 2103-2134.

Patro, Dilip K., \& Wald, John K. 2005. Firm characteristics and the impact of emerging market liberalizations. Journal of banking \& finance, 29(7), 1671-1695.

Pinkowitz, Lee, Stulz, Rene, \& Williamson, Rohan. 2006. Does the Contribution of Corporate Cash Holdings and Dividends to Firm Value Depend on Governance? A Cross-country Analysis. Journal of finance, 61(6), 2725-2751.

Porta, Rafael La, Lopez-De-Silanes, Florencio, Shleifer, Andrei, \& Vishny, Robert. 2002. Investor Protection and Corporate Valuation. Journal of finance, 57(3), 1147-1170.

Quinn, Dennis P., \& Toyoda, A. Maria. 2008. Does Capital Account Liberalization Lead to Growth? Review of financial studies, 21(3), 1403-1449.

Rajan, Raghuram G., \& Zingales, Luigi. 2003. The great reversals: the politics of financial development in the twentieth century. Journal of financial economics, 69(1), 5-50.

Riddick, Leigh A., \& Whited, Toni M. 2009. The Corporate Propensity to Save. Journal of finance, 64(4), 1729-1766.

Stulz, Rene M. 1999. Globalization, Corporate Finance, And The Cost Of Capital. Journal of applied corporate finance, 12(3), 8-25.

Stulz, Rene M. 2005. The Limits of Financial Globalization. Journal of finance, 60(4), 1595-1638.

To, Thomas Y., Navone, Marco, \& Wu, Eliza. 2018. Analyst coverage and the quality of corporate investment decisions. Journal of corporate finance, $\mathbf{5 1 ,} 164-181$. 
Ward, Charles, Yin, Chao, \& Zeng, Yeqin. 2018. Institutional investor monitoring motivation and the marginal value of cash. Journal of corporate finance, 48, $49-75$.

Wu, Weijun, Yang, Yang, \& Zhou, Sili. 2017. Multinational firms and cash holdings: Evidence from china. Finance research letters, 20, $184-191$. 


\section{Highlights}

\section{Foreign Institutional Ownership and Corporate Cash Holdings}

- The paper investigates the effect of foreign institutional ownership on corporate cash holdings in an emerging markets setting.

- Results indicate that while foreign institutional ownership is associated to reductions in cash holdings, foreign institutions also increase the contribution of cash to firm value.

- These effects are potentially transmitted to cash and valuation through the mitigation of agency costs and alleviation of financing constraints.

- The results from the paper suggest beneficial effects of foreign institutional ownership on firms' financing structure, as foreign institutions contribute to a more efficient and value-enhancing cash management. 